\title{
TINGKAT KONSUMSI ZAT GIZI DAN STATUS GIZI MANULA DI SASANA TRESNA WERDHA (STW) PROVINSI BENGKULU
}

\author{
ISMED \\ Akademi Kebidanan Salma \\ ismedismail@ymail.com
}

\begin{abstract}
It is estimated that the number of seniors will continue to increase, in line with the decline in infant mortality. One of the important things that need to be considered to anticipate this is to increase attention to the nutritional status of the elderly. Nutritional status is a reflection of the quality of the food it consumes. This study aims to observe the description of nutrient consumption and nutritional status of the elderly in Sasana Tresna Wherda Bengkulu. This research is descriptive in nature, using primary data and secondary data. Data processed manually. The consumption of nutrients for the elderly is still below the recommended dietary allowance or RDA (recommended dietary allowances), especially for vitamin A, vitamin $\mathrm{C}, \mathrm{Fe}$, and $\mathrm{Ca}$. The availability of nutrients at the orphanage for calories, protein, and vitamin $B$ is adequate, however, $\mathrm{Ca}, \mathrm{Fe}$, vitamin $\mathrm{A}$ and vitamin $\mathrm{C}$ are not yet as recommended. The nutritional status or stature of the elderly in general is thin, namely $81.3 \%$ for men and $62.5 \%$ for women. Elderly who consume moderate and poor nutritional substances, nutritional status of the elderly is found thin, but elderly people who consume enough are also underweight.
\end{abstract}

Keywords: Nutritional Substance, Nutritional Status, Elderly

\begin{abstract}
Abstrak: Diperkirakan jumlah manula akan terus meningkat, sejalan dengan menurunnya angka kematian bayi. Salah satu hal penting yang perlu diperhatikan untuk mengantisipasi hal tersebut adalah meningkatkan perhatian pada status gizi manula. Status gizi merupakan refleksi dari mutu makanan yang dikonsumsinya. Penelitian ini bertujuan untuk mengamati gambaran konsumsi zat gizi dan status gizi manula yang ada di Sasana Tresna Wherda Bengkulu. Penelitian ini bersifat dekriptif, dengan menggunakan data primer dan data sekunder. Data diolah secara manual. Konsumsi zat gizi manula masih dibawah batas kecukupan gizi yang dianjurkan atau RDA (recomended dietary allow-ances) terutama untuk vitamin A, vitamin C, Fe, dan Ca. Ketersediaan zat gizi di Panti untuk kalori, protein, dan vitamin B sudah memadai, akan tetapi $\mathrm{Ca}, \mathrm{Fe}$, vitamin $\mathrm{A}$ dan vitamin $\mathrm{C}$ belum sesuai dengan yang dianjurkan. Status gizi atau perawakan manula pada umumnya adalah kurus yaitu 81,3\% untuk laki-laki dan 62,5\% untuk perempuan. Manula yang konsumsi zat gizinya sedang dan buruk, status gizi manula ditemui kurus, akan tetapi manula yang konsumsi nya cukup juga ada yang berstatus gizi kurus.
\end{abstract}

Kata Kunci : Zat Gizi, Status Gizi, Manula

\section{A. Pendahuluan}

Salah satu hasil dari pembangunan nasional, khusunya bidang kesehatan adalah meningkatnya umur harapan hidup, sebagai dampak dari menurunnya angka kematian khususnya bayi dan anak balita serta kematian pada umumnya. Beberapa faktor yang dapat mempengaruhi umur harapan hidup menjadi lebih panjang adalah kemajuan tingkat kesehatan, sosial ekonomi, kemajuan ilmu kedokteran, kebersihan lingkungan, 
kemajuan dibidang teknologi pangan dan keadaan gizi yang baik. Keadaan (status) gizi seseorang merupakan refleksi dari mutu makanan yang dimakan sehari-hari, maka susunan makanan sebaiknya memenuhi kebutuhan gizi tubuh, seandainya hal ini tidak tercapai maka akan menyebabkan keadaan gizi lebih atau keadaan gizi kurang yang biasa disebut juga dengan gizi salah (malnutrition).

Walaupun pada masa tua sebagaian besar tubuh telah mengakhiri pertumbuhannya, ukuran tubuh dan jaringan harus tetap dipelihara. Pada masa usia lanjut (usila), zat gizi yang bermutu baik tetap diperlukan untuk membentuk jaringan tubuh, terutama dalam penggantian jaringan yang telah rusak. Gizi yang lengkap dan seimbang akan sangat membantu manusia lanjut (manula) untuk tetap hidup kuat, sehat dan bugar. Lebih jauh ahli Gerentologi dan ahli Geriatri berpendapat bahwa 30\% sampai $50 \%$ faktor gizi berperan penting dalam mencapai dan mempertahankan keadaan optimal pada golongan usila. Menyadari proporsi penduduk berusia 55 tahun ke atas akan meningkat, sejalan dengan peningkatan dan membaiknya sosial ekonomi dan sosial budaya bangsa dimasa datang maka perlu dilakukan pengkajian yang mendalam tentang upaya-upaya peningkatan kulaitas sumber daya manusia. Upaya peningkatan sumber daya termasuk usila ini dilaksanakan melalui upaya penyebarluasan informasi dan peningkatan pengetahuan menuju pembinaan usila dengan melaksanakan studi untuk mendukung metode penyelenggaraannya. Usia lanjut yang merupakan sumberdaya bernilai tinggi sesuai dengan pengetahuan dan pengalaman kehidupan yang dimilikinya, yang dapat dimanfaatkan untuk meningkatkan mutu kehidupan masyarakat keseluruhannya.

Pada umumnya manula menikmati hari tuanya dalam lingkungan keluarga, namun karena sesuatu hal tersebut tidak berlaku sama. Untuk itu dibutuhkan suatu lembaga kesejahteraan sosial bagi manula yang dapat menampung mereka yaitu Sasana Tresna Werdha (STW). Di provinsi Bengkulu mempunyai satu STW yang dikelola oleh Pemerintah. STW Bengkulu tidak hanya menerima manula dalam wilayah Bengkulu saja akan tetapi juga provinsi terdekat. Tujuan Khusus dari penelitian ini adalah untuk mengetahui konsumsi zat gizi bagi manula, konsumsi zat gizi rata-rata, status gizi manula melalui $\mathrm{BB}$ dan $\mathrm{TB}$, mengetahui pendidikan dan pekerjaan waktu muda manula, mengetahui penyakit yang diderita manula saat ini dan kebiasaan hidup manula.

\section{B. Metodologi Penelitian}

Jenis penelitian ini adalah analitik dengan desain cross sectional. Sampel dari penelitian ini sebanyak 16 orang laki-laki dan 16 orang perempuan. Penelitian ini dilakukan selama 7 hari dan data yang dikumpulkan meliputi konsumsi makanan, pendidikan manula, pekerjaan manula diwaktu muda, penyakit yang diderita saat ini dan status gizi manula itu sendiri. Sedangan untuk konsumsi makanan ditentukan dengan cara gabungan antara metode Food Weight (penimbangan makanan) dengan Food recall (menanyakan kembali makanan kemarennya yang dimakan manula selama 2 hari berturut-turut). Konsumsi makanan tersebut akan dibandingkan dengan kecukupan gizi yang dianjurkan untuk manula. Setelah konsumsi selama dua hari tersebut didapatkan selanjutnya dicari rata-rata gizi yang dikonsumsi selama dua hari tersebut. Data tentang gaya hidup, pendidikan, pekerjaan diwaktu muda dan penyakit yang diderita sekarang dengan menggunakan kuesioner. Serta penentuan status gizi didapatkan dengan pengukuran $\mathrm{BB}$ dan $\mathrm{TB}$ dan setelah itu status gizi ditentukan dengan menggunakan Body Mass Index (BMI). Semua data yang ada ditabulasikan dan diolah secara manual. 


\section{Hasil Dan Pembahasan}

Tabel 1. Distribusi Usia Manula menurut Jenis Kelamin

\begin{tabular}{cccccccc}
\hline & Umur (tahun) & \multicolumn{2}{c}{$\begin{array}{c}\text { Laki- } \\
\text { laki }\end{array}$} & \multicolumn{2}{c}{$\begin{array}{c}\text { Perempua } \\
\text { n }\end{array}$} & \multicolumn{2}{c}{ Total } \\
\cline { 2 - 7 } & $\mathrm{n}$ & $\%$ & $\mathrm{n}$ & $\%$ & $\mathrm{n}$ & $\%$ \\
\hline $60-64$ & 7 & 43, & 5 & 31,3 & 1 & 37, \\
& & 8 & & & 2 & 5 \\
$65-69$ & & 18, & 5 & 31,3 & 8 & 25, \\
& & & 8 & & & & 0 \\
$70-74$ & 1 & 6,2 & 1 & 6,2 & 2 & 6,2 \\
$75-79$ & 2 & 12, & 2 & 12,5 & 4 & 12, \\
& & 5 & & & & 5 \\
$80-84$ & 2 & 12, & 1 & 6,2 & 3 & 9,4 \\
& & & 5 & & & & \\
$85+$ & 1 & 6,2 & 2 & 12,5 & 3 & 9,4 \\
\hline Jumlah & 1 & 100 & 16 & 100 & 3 & 100 \\
& 6 & & & & 2 & \\
\hline
\end{tabular}

Dari tabel diatas terlihat bahwa usia manuladi STW pada umumnya 60-64 tahun yaitu 43,8 \% untuk laki-laki dan 31,3\% untuk perempuan. Sedangkan secara keseluruhan atau gabungan antara laki-laki dan perempuan umur yang terbanyak juga berkisar antara 60-64 yaitu sebesar 37,5\%.

Tabel 2. Distribusi Lama tinggal Manula menurut jenis kelamin

\begin{tabular}{cccccccc}
\hline & Lama Tinggal & \multicolumn{2}{c}{ Laki- } & \multicolumn{2}{c}{ Perempua } & \multicolumn{2}{c}{ Total } \\
& laki & & n & & & \\
\cline { 2 - 7 } & & $\mathrm{n}$ & $\%$ & $\mathrm{n}$ & $\%$ & $\mathrm{n}$ & $\%$ \\
\hline $1-4$ & 8 & 50, & 9 & 56,3 & 1 & 53, \\
& & & 0 & & & 7 & 1 \\
$5-9$ & 4 & 25, & 4 & 25,0 & 8 & 25, \\
& & & 0 & & & & 0 \\
$10+$ & 4 & 25, & 3 & 18,7 & 7 & 21, \\
& & & 0 & & & & 9 \\
Jumlah & 1 & 100 & 16 & 100 & 3 & 100 \\
& 6 & & & & 2 & \\
\hline
\end{tabular}

Dari tabel diatas terlihat bahwa manula umumnya tinggal di Panti rata-ta 1-4 tahun yaitu $50 \%$ atau lebih..

Tabel 3. Distribusi Tingkat Pendidikan Manula menurut Jenis kelamis

\begin{tabular}{|c|c|c|c|c|c|c|}
\hline \multirow[t]{2}{*}{ Tingkat Pendidikan } & \multicolumn{2}{|c|}{$\begin{array}{l}\text { Laki- } \\
\text { laki }\end{array}$} & \multicolumn{2}{|c|}{$\begin{array}{c}\text { Perempua } \\
\text { n }\end{array}$} & \multicolumn{2}{|c|}{ Total } \\
\hline & $\bar{n}$ & $\%$ & $\mathrm{n}$ & $\%$ & $\mathrm{n}$ & $\%$ \\
\hline Tidak sekolah & 5 & $\begin{array}{c}31, \\
3\end{array}$ & 14 & 87,6 & $\begin{array}{l}1 \\
9\end{array}$ & $\begin{array}{c}59 \\
4\end{array}$ \\
\hline Tidak tamat SD & 6 & $\begin{array}{c}37 \\
5\end{array}$ & 1 & 6,2 & 7 & $\begin{array}{c}21, \\
9\end{array}$ \\
\hline Tamat SD & 1 & 6,2 & - & 0,0 & 1 & 3,1 \\
\hline
\end{tabular}




\begin{tabular}{lcccccc} 
Tamat SLTP+ & 4 & 25, & 1 & 6,2 & 5 & 15, \\
& & 0 & & & & 6 \\
Jumlah & 1 & 100 & 16 & 100 & 3 & 100 \\
& 6 & & & & 2 & \\
\hline
\end{tabular}

Dari Tabel diatas jelas terlihat bahwa pendidikan manula sangat rendah sekali. Hal ini terutama terlihat pada manula perempuan yaitu sebesar $87,6 \%$ sedangkan lakilaki sebesar 31,3\%. Secara umum laki-laki dan perempuan yang tidak pernah sekolah sebesar 59,4\%.

Tabel 4. Distribusi Pekerjaan Manula Waktu Muda Menurut Jenis Kelamin

\begin{tabular}{|c|c|c|c|c|c|c|}
\hline \multirow[t]{2}{*}{ Pekerjaan } & \multicolumn{2}{|c|}{$\begin{array}{c}\text { Laki- } \\
\text { laki }\end{array}$} & \multicolumn{2}{|c|}{$\begin{array}{c}\text { Perempua } \\
\text { n }\end{array}$} & \multicolumn{2}{|c|}{ Total } \\
\hline & $\mathrm{N}$ & $\%$ & $\mathrm{n}$ & $\%$ & $\bar{n}$ & $\%$ \\
\hline Tidak Bekerja & - & - & 5 & 31,3 & 5 & $\begin{array}{c}15, \\
7\end{array}$ \\
\hline Petani & 9 & $\begin{array}{c}56, \\
3\end{array}$ & 10 & 62,5 & $\begin{array}{l}1 \\
9\end{array}$ & $\begin{array}{c}59, \\
4\end{array}$ \\
\hline PN/ABRI & 2 & $\begin{array}{c}12 \\
5\end{array}$ & - & - & 2 & 6,2 \\
\hline Wiraswasta & 4 & $\begin{array}{c}25 \\
0\end{array}$ & 1 & 6,2 & 5 & $\begin{array}{c}15, \\
7\end{array}$ \\
\hline Buruh & 1 & 6,2 & - & - & 1 & 3,1 \\
\hline Jumlah & $\begin{array}{l}1 \\
6\end{array}$ & 100 & 16 & 100 & $\begin{array}{l}3 \\
2\end{array}$ & 100 \\
\hline
\end{tabular}

Dari Tabel diatas terlihat bahwa pekerjaan manula diwaktu muda yang utama pada umumnya adalah petani baik laki-laki maupun perempuan yaitu masing-masing sebesar $56,3 \%$ dan $62,5 \%$.

Tabel 5. Distribusi Penyakit yang diderita manula menurut Jenis Kelamin

\begin{tabular}{lcccc}
\hline \multicolumn{1}{c}{ Pekerjaan } & \multicolumn{3}{c}{$\begin{array}{c}\text { Laki- } \\
\text { laki }\end{array}$} & Perempuan \\
\cline { 2 - 5 } & $\mathrm{N}$ & $\%$ & $\mathrm{n}$ & $\%$ \\
\hline Tidak Pernah Sakit & 2 & 11,0 & 2 & 9,6 \\
$\quad$ Reumatik & 9 & 50,0 & 15 & 46,9 \\
$\quad$ Katarak & 2 & 11,0 & 2 & 9,1 \\
Gangguan Pernafasan & 5 & 27,8 & 3 & 13,6 \\
Gangguan Pencernaan & - & - & - & - \\
Jumlah & 16 & 100 & 16 & \\
\hline
\end{tabular}

Dari data di atas terlihat ada beberapa responden yang menderita lebih dari satu penyakit. Menurut hasil penelitian Hadi Martono menunjukan bahwa penderita berusia 80 tahun atau lebih yang dirawat di Rumah Sakit terkenal di Semarang hanya 10\% yang menderita satu penyakit, sedangkan lebih dari $50 \%$ menderita tiga atau lebih penyakit. 
Tabel 6. Distribusi Kebiasaan Manula (Kebiasaan Merokok, Minum Minuman Keras, Minum Kopi)

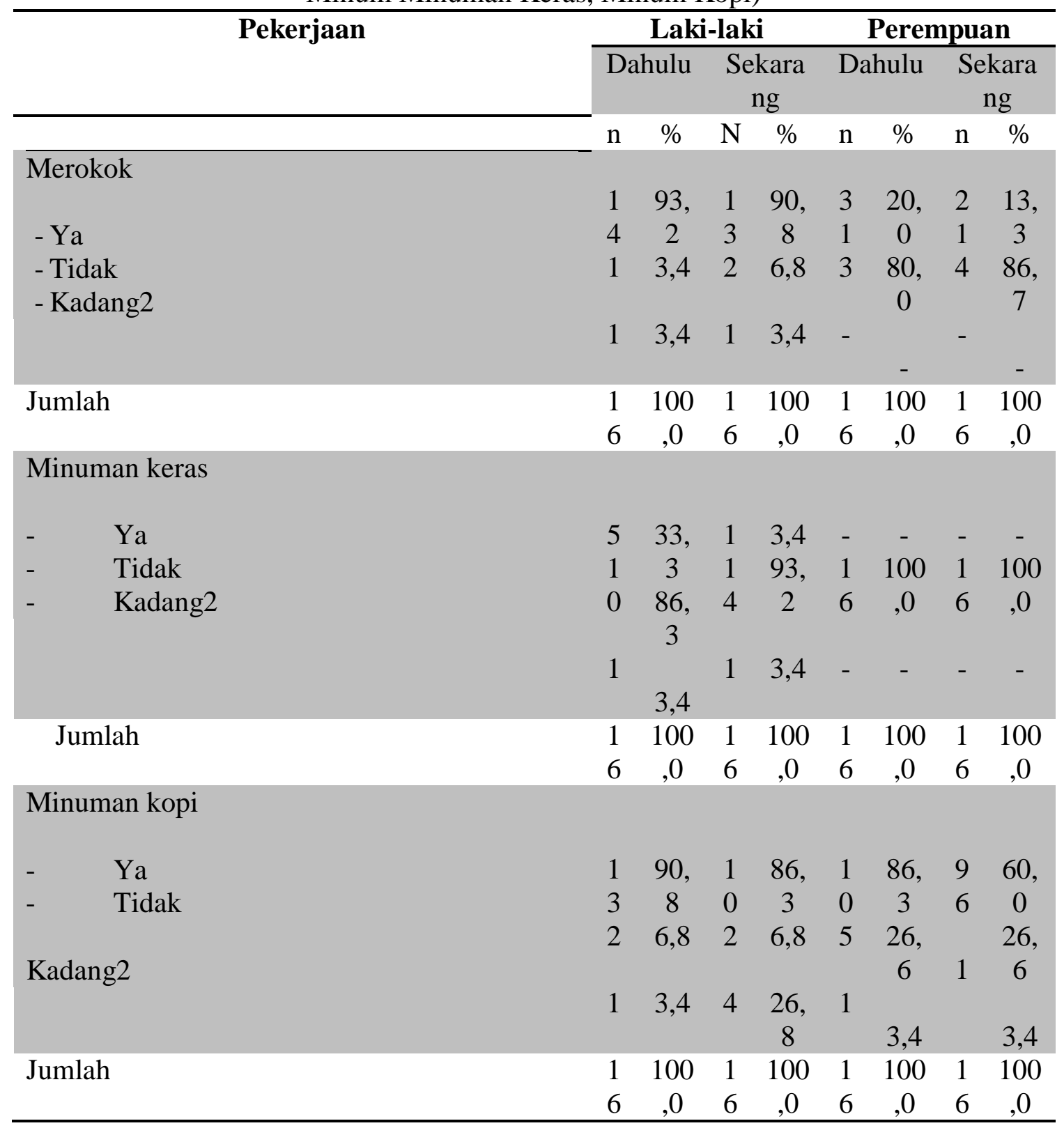

Pada Tabel diatas terlihat bahwa manula laki-laki adalah perokok, baik dahulu maupun sekarang. Dimana dahulu adalah sebesar 91,1\% sedangkan sekarang adalah $86,6 \%$ yang merokok. Sedangkan manula perempuan pada umumnya tidak perokok, walaupun ada juga yang merokok tetapi angkanya kecil yaitu $20 \%$ dan menurun angkanya saat penelitian dilaksanakan. Kebiasaan minum minuman keras (mengandung alkohol) ternyata manula tidak peminum, dari responden ditemukan bahwa dahulu $33,3 \%$ adalah peminum, sedangkan sekarang turun menjadi $6,7 \%$. Bila dilihat baik manula laki-laki maupun perempuan tidak peminum keras

Dari kebiasaan minum kopi ternyata angkanya cukup tinggi baik untuk manula laki-laki maupun manula perempuan yaitu masing-masing $86,6 \%$ dan $66,7 \%$. 
Tabel 7. Rata-rata konsumsi zat gizi Manula menurut jenis kelamin

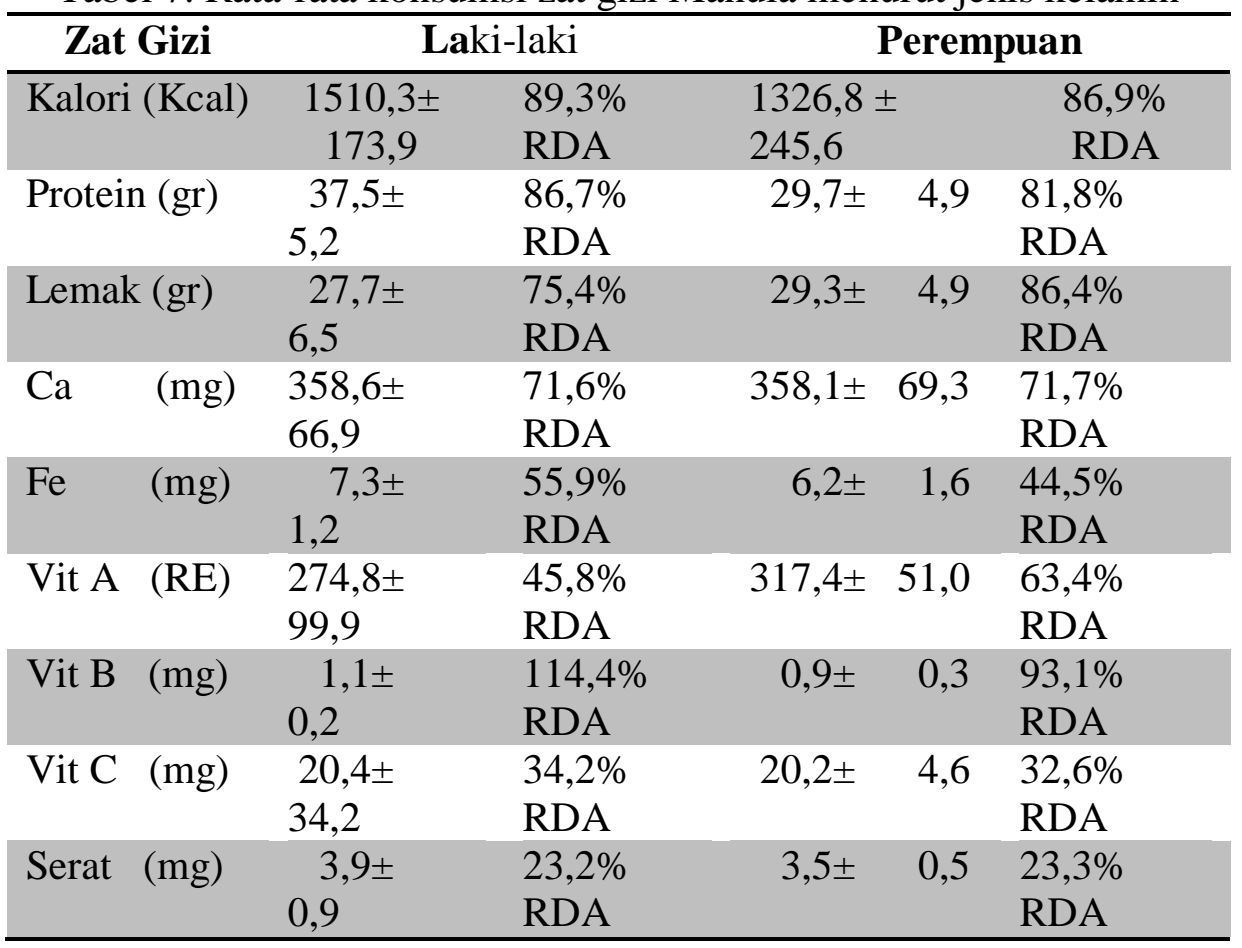

Dari Tabel diatas terlihat dengan jelas bahwa manula di STW Bengkulu masih mengkonsumsi zat gizi dibawah kecukupan yang dianjurkan, kecuali untuk vitamin B bagi manula laki-laki telah dikonsumsi sesuai dengan kecukupan yaitu $1,1 \mathrm{mg}$ atau $114 \%$ RDA.

Tabel 8. Ketersediaan Zat Gizi yang Akan Dikonsumsi Manula Dibandingkan Dengan RDA

\begin{tabular}{|c|c|c|c|c|c|c|}
\hline \multirow[t]{2}{*}{ Jenis Zat Gizi } & \multicolumn{3}{|c|}{ Laki-laki } & \multicolumn{3}{|c|}{ Perempuan } \\
\hline & $\begin{array}{c}\text { Sedi } \\
\text { aan }\end{array}$ & Keb & $\begin{array}{l}\% \mathrm{R} \\
\mathrm{DA}\end{array}$ & $\begin{array}{c}\text { Sedi } \\
\text { aan }\end{array}$ & $\begin{array}{l}\mathrm{Ke} \\
\text { b. }\end{array}$ & $\begin{array}{l}\% \mathrm{R} \\
\mathrm{DA}\end{array}$ \\
\hline Kalori (Kcal) & $\begin{array}{c}1710 \\
, 0\end{array}$ & $\begin{array}{l}170 \\
0,0\end{array}$ & $\begin{array}{c}100 \\
5\end{array}$ & $\begin{array}{c}1500 \\
, 0\end{array}$ & $\begin{array}{l}15 \\
43\end{array}$ & 97,8 \\
\hline Protein (gr) & 44,5 & 46,0 & 96,7 & 29,5 & $\begin{array}{c}34 \\
3\end{array}$ & 86,0 \\
\hline Lemak (gr) & 30,7 & 37,7 & 81,4 & 28,6 & $\begin{array}{c}31 \\
9\end{array}$ & 89,6 \\
\hline Serat (gr) & 11,8 & 16,9 & 69,8 & 10,5 & $\begin{array}{c}15 \\
3\end{array}$ & 68,6 \\
\hline $\mathrm{Ca} \quad(\mathrm{mg})$ & $\begin{array}{l}360 \\
1\end{array}$ & $\begin{array}{l}500, \\
0\end{array}$ & 40,6 & $\begin{array}{c}350 \\
2\end{array}$ & $\begin{array}{c}50 \\
0,0\end{array}$ & 70,5 \\
\hline Vit A $\quad(\mathrm{RE})$ & $\begin{array}{l}334, \\
0\end{array}$ & $\begin{array}{c}600 \\
0\end{array}$ & 55,7 & $\begin{array}{c}343 \\
1\end{array}$ & $\begin{array}{l}50 \\
0,0\end{array}$ & 68,6 \\
\hline Vit B (mg) & 1,3 & 1,0 & $\begin{array}{c}130 \\
0\end{array}$ & 1,1 & 1,0 & $\begin{array}{c}100 \\
0\end{array}$ \\
\hline Vit C $\quad(m g)$ & 33,3 & 60,0 & 55,5 & 30,0 & $\begin{array}{c}60 \\
0 \\
\end{array}$ & 50,0 \\
\hline
\end{tabular}


Pada Tabel 8 kelihatan dari makanan yang diberikan dapat diperkirakan ketersediaan zat gizi yang akan dikonsumsi oleh manula yang berada di panti. Dari penelitian ini ditemukan bahwa untuk kalori baik untuk manula laki-laki maupun untuk manula perempuan dapat dikatakan telah dipenuhi sesuai dengan RDA.

Tabel 9. Konsumsi Zat Gizi Manula Menurut Jenis Kelamin Berdasarkan Kategori NKRG di STW

\begin{tabular}{|c|c|c|c|c|c|c|}
\hline \multirow[t]{2}{*}{ Kategori } & \multicolumn{2}{|c|}{$\begin{array}{c}\text { Laki- } \\
\text { laki }\end{array}$} & \multicolumn{2}{|c|}{$\begin{array}{c}\text { Perempua } \\
\text { n }\end{array}$} & \multicolumn{2}{|c|}{ Total } \\
\hline & $\mathrm{N}$ & $\%$ & $\mathrm{n}$ & $\%$ & $\mathrm{n}$ & $\%$ \\
\hline Baik & - & - & - & - & - & - \\
\hline Cukup & 7 & $\begin{array}{c}43 \\
7\end{array}$ & 8 & 50,0 & $\begin{array}{l}1 \\
5\end{array}$ & 46,9 \\
\hline Sedang & 5 & $\begin{array}{c}31, \\
3\end{array}$ & 4 & 25,0 & 9 & 28,1 \\
\hline Buruk & 4 & $\begin{array}{c}25 \\
0\end{array}$ & 4 & 25,0 & 8 & 25,0 \\
\hline Total & $\begin{array}{l}1 \\
6\end{array}$ & 100 & 16 & 100 & $\begin{array}{l}3 \\
2\end{array}$ & $\begin{array}{c}100 \\
0\end{array}$ \\
\hline
\end{tabular}

Bila kita perhatikan Tabel 9 diatas dapat dilihat bahwa manula laki-laki dan perempuan konsumsi kategori cukup angkanya cukup tinggi yaitu berturut-turut 7 orang $(43,7 \%)$ dan 8 orang $(50,0 \%)$. Sedangkan manula yang konsumsi zat gizinya tergolong buruk adalah 4 orang $(25,0 \%)$ untuk manula laki-laki dan perempuan.

Tabel 10. Status Gizi Manula Menurut Jenis Kelamin Di STW

\begin{tabular}{|c|c|c|c|c|c|c|}
\hline \multirow[t]{2}{*}{ Pekerjaan } & \multicolumn{2}{|c|}{$\begin{array}{c}\text { Laki- } \\
\text { laki }\end{array}$} & \multicolumn{2}{|c|}{$\begin{array}{l}\text { Perempu } \\
\text { an }\end{array}$} & \multicolumn{2}{|c|}{ Total } \\
\hline & $\bar{N}$ & $\%$ & $\mathrm{n}$ & $\%$ & $\bar{n}$ & $\%$ \\
\hline Gemuk & - & - & - & - & - & - \\
\hline Normal & 3 & 18,7 & 6 & 37,5 & 9 & 28,1 \\
\hline Kurus & $\begin{array}{l}1 \\
3\end{array}$ & 81,3 & 10 & 62,5 & $\begin{array}{l}2 \\
3\end{array}$ & 71,9 \\
\hline Total & $\begin{array}{l}1 \\
6 \\
\end{array}$ & $\begin{array}{c}100 \\
0\end{array}$ & 16 & 100 & $\begin{array}{l}3 \\
2 \\
\end{array}$ & $\begin{array}{c}100 \\
0\end{array}$ \\
\hline
\end{tabular}

Pada Tabel. 10 diatas terlihat dengan jelas bahwa manula yang berperawakan normal cukup rendah baik untuk laki-laki maupun untuk perempuan masing-masing 3 orang $(18,7 \%)$ dan 6 orang $(37,5 \%)$. Angka manula yang berperawakan kurus lebih tinggi pada manula laki-laki dari perempuan 13 orang $(81,3 \%)$. Hasil status gizi manula ditentukan berdasarkan kategori Body Mass Index (BMI) yaitu BB/TB ${ }^{2}$. Dari pengukuran berat badan (BB), didapatkan rata-rata berat badan $34 \mathrm{~kg} \pm 2,5 \mathrm{~kg}$ untuk wanita dan $42 \mathrm{~kg} \pm 3,5$ untuk laki-laki. Sedangkan untuk tinggi badan (TB) diperoleh rata-rata $145 \mathrm{~cm} \pm 7,5$ untuk manula perempuan dari $153 \mathrm{~cm} \pm 8,3$ untuk manula lakilaki.

Tabel 11. Status Gizi Manula Berdasarkan Konsumsi Zat Besi Di Sasana Tresna Werdha Bengkulu

\begin{tabular}{ccccc}
\hline Status & \multicolumn{3}{c}{ Konsumsi Zat Gizi } & Total \\
\cline { 3 - 5 } Gizi & Cukup & Sedang & Buruk & \\
\cline { 3 - 5 } & $\mathrm{N}$ & $\mathrm{N}$ & $\mathrm{N}$ &
\end{tabular}

252 Lembaga Penelitian dan Penerbitan Hasil Penelitian Ensiklopedia $\quad$ E-ISSN: 2657-0300 


\begin{tabular}{|c|c|c|c|c|}
\hline & $\%$ & $\%$ & $\%$ & \\
\hline \multirow{2}{*}{ Normal } & \multirow{2}{*}{60,0} & - & - & \multirow[t]{2}{*}{9} \\
\hline & & - & - & \\
\hline \multirow[t]{2}{*}{ Kurus } & 6 & 9 & 8 & \multirow[t]{2}{*}{23} \\
\hline & 40,0 & 100,0 & 100,0 & \\
\hline \multirow[t]{2}{*}{ Total } & 15 & 9 & 8 & \multirow[t]{2}{*}{32} \\
\hline & 100,0 & 100,0 & 100,0 & \\
\hline
\end{tabular}

Dari Tabel 11 diatas dapat dilihat juga bahwa manula yang konsumsi zat gizinya cukup, ternyata ada yang berperawakan kurus yaitu 40,0 \%. Konsumsi zat gizi manula yang buruk ternyata status gizi (perawakannya) adalah kurus, begitu juga dengan manula yang konsumsi zat gizinya sedang.

Dari hasil penelitian menunjukkan bahwa sebagian besar pendidikan manula masih rendah. Sejumlah 59,4 \% masih buta huruf atau tidak pernah sekolah sama sekali. Dengan rendahnya tingkat pendidikan manula tersebut, maka akan rendah juga pengetahuannya akan kesehatan dan gizi.

Dari tabel 4 tentang pekerjaan manula diwaktu muda, terbesar presentasinya adalah sebagai petani, khusunya bagi laki-laki yaitu 56,3 \%. Hal ini tentu akan mempunyai implikasi terhadap kesehatan manula saat ini. Hal ini terlihat dari penyakit yang diderita manula (tabel 5), penyakit yang terbanyak adalah reumatik baik untuk laki-laki maupun perempuan masing-masing 50,0 \% dan 68,2 \%. Dari angka ini terlihat bahwa manula perempuan angka penyakit reumatik ini lebih tinggi, dimana hal ini sesuai dengan penelitian-penelitian sebelunya. Dari tabel 5 ini juga terlihat bahwa manula menderita lebih dari satu penyakit. Menurut Hadi Martono ${ }^{45}$, penderita berusia 80 tahun atau lebih yang ada di Rumah Sakit terkenal di Semarang hanya $10 \%$ yang menderita satu penyakit, sedangkan lebih dari $50 \%$ menderita tiga atau lebih penyakit.

Dari penyakit gangguan pernafasan yang diderita manula laki-laki $(28,8 \%)$, hal ini dapat disebabkan oleh kebiasaan merokok dari manula (tabel 6) yaitu sebesar 87,6 $\%$ dahulu maupun sekarang. Perempuan yang menderita penyakit gangguan pernafasan adalah sebesar 113,6 \%, dimana yang mempunyai kebiasaan merokok adalah 18,7\% dan sekarang telah menurun menjadi $12,5 \%$. Dari kebiasaan minum kopi manula (tabel 6), terlihat bahwa pada umumnya manula, baik laki-laki maupun perempuan adalah peminum kopi, hal ini tentu erat kaitannya dengan penyakit gangguan pencernaan. Dari penelitian ini tidak ditemukan manula yang menderita penyakit gangguan pencernaan.

Konsumsi zat gizi manula pada umumnya masih dibawah RDA (Recomended Dietary Allowances) atau kebutuhan yang dianjurkan sehari. Dari tabel 7 terlihat dengan jelas hanya vitamin B yang dikonsumsi manula laki-laki sesuai dengan RDA. Hal ini dapat disebabkan karena variasi menu, cita rasa, tekstur, dan lain-ain. Hal ini yang lebih penting adalah menurunnya nafsu makan manula, yang disebabkan karena kepekaan indra pencium telah mengalami penurunan, produksi asam lambung berkukrang. Produksi asam lambung meliputi volume, keasaman dan jumlah pepsin yang ada. Selain itu gigi yang tidak lengkap dan alat pencernaan yang melemah, sehingga menimbulkan rasa tidak enak diperut.

Rendahnya konsumsi semua zat gizi yang dikonsumsi manula, mengakibatkan berbagai penyakit menunggu untuk masuk dikala daya tahan tubuh manula melemah, seperti dengan rendahnya proten maka fungsinya sebagai pemelihara dan pengganti sel-sel jaringan yang telah rusak akan berkurang atau tidak ada sama sekali. Selanjutnya kekurangan $\mathrm{Ca}$ akan dapat menyebabkan cepatnya terjadi proses 
osteoporosis. Manula akan cepat lelah apabila kekurangan Fe dan akan mengalami gangguan penglihatan bila kekurangan vit A. Selanjutnya yang sangat perlu mendapatkan perhatian adalah manula sangat rendah sekali mengkonsumsi serat, dimana serat akan sangat diperlukan sekali dalam mencegah penyakit jantung koroner, mencegah kanker usus besar, mencegah kencing manis dan mencegah penyakit divertikuler.

Ketersediaan zat gizi oleh panti untuk kalori, protein, lemak dan vitamin B telah mendekati RDA, sedangkan serat, vitamin $\mathrm{C}$ dan Fe belum disediakan sesuai dengan RDA manula yang berada di Panti. Bila dilihat menu yang disediakan oleh panti, ternyata kurang bervariasi seperti makan pagi Selanjutnya dari menu yang disusun oleh Panti relatif sering menggunakan lauk nabati. Dilain pihak manula memerlukan protein yang bermutu tinggi. Pada umumnya manula laki-laki adalah berperawakan kurus. Hal ini dapat disebabkan karena kurangnya konsumsi energi kecukupan yang mengakibatkan tubuh menggunakan cadangan dari lemak dibawah kulit untuk memenuhi kebutuhannya. Manula yang konsumsi zat gizinya sedang dan buruk, ternyata memiliki status gizi (perawakan) yang kurus, sedangkan manula yang konsumsi zat gizinya cukup ternyata juga memiliki status gizi kurus, setelah diteliti ternyata manula tersebut sedang mengalami sakit.

\section{Penutup}

Hasil studi ini menggambarkan konsumsi zat gizi masih dibawah Recomended Dietary Allowance (RDA), kecuali vitamin B bagi manula laki-laki telah sesuai dengan RDA, sedangkan konsumsi Vitamin $\mathrm{C}$ dan serat masih dibawah 35\% RDA. Penyakit yang terbanyak diderita manula adalah reumatik dan lebih tinggi angkanya pada manula perempuan dan beberapa manula menderita lebih dari satu penyakit. Pada umumnya manula laki-laki sekarang adalah perokok $(90,8 \%)$ dan tidak menunjukan angka yang menurun dari dahulu sampai sekarang. Sedangkan kebiasaan minum kopi baik manula laki-laki maupun perempuan adalah suka minum kopi, akan tetapi tidak menunjukkan adanya penyakit gangguan pencernaan pada manula. Manula yang konsumsi zat gizinya sedang dan kurang status gizi atau perawakannya kurus. Sedangkan manula yang mengkonsumsi zat gizinya cukup memiliki gizi baik lebih besar. Status gizi (perawakan) manula pada umumnya adalah kurus. Angkanya lebih tinggi pada manula perempuan.

\section{Daftar Pustaka}

Almatsier. (2010). Prinsip dalam Ilmu Gizi. Jakarta : PT Gramedia Pustaka Utama

Andriani, M., dan Wirjatmadi, B. (2014). Peran Gizi dalam Siklus Kehidupan.Jakarta: Kencana Persada Media Group

Agus, Zulkarnain. (1984). Gizi pada usia lanjut dan beberapa masalahnya. FK UNAND, Padang.

Astawan, Made dan Mita Wahyuni. 2004. Gizi dan Kesehatan Manula. Jakarta. PT Melton Putra

Berg. (1986). Peranan gizi dalam pembangunan Nasional. Rajawali. Jakarta

Depkes RI. (2001). Profil Kesehatan Indonesia 2001 Menuju Indonesia Sehat 2010. Jakarta

Khomsan, Ali. (2003) Pangan dan Gizi untuk kesehatan. Jakarta. PT Raja Grafindo Persada 
Notoatmodjo, S. (2010). Metodologi Penelitian Kesehatan. Jakarta : Rineka Cipta

Salazar, Muhammad. (2005) Faktor-faktor yang berhubungan dengan asupan energi dan protein pada Lansia di Panti Tresna Werdha Teratai Palembang. FKM Universitas Sriwijaya.

Suparisa, I.D.N. dkk.2013. Penilaian status Gizi. Jakarta: Penerbit Buku Kedokteran EGC

Sjahmien Moehji. (2002). Ilmu Gizi I Pengetahuan Dasar ilmu Gizi. Jakarta: Papas Sinar Sinanti

Suhardjo. (2003). Peranan Pangan dan Gizi. Jakarta : Bumi Aksara 